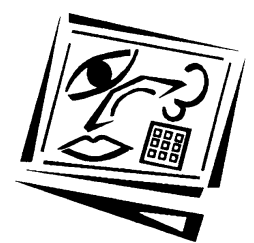

\title{
Does the use of technology make a difference in the geometric cognitive growth of pre-service mathematics teachers?
}

\author{
Gerrit Stols \\ University of Pretoria
}

\begin{abstract}
This study investigated the geometric cognitive growth of pre-service mathematics teachers in terms of the Van Hiele levels in a technology-enriched environment, as opposed to that of students in a learning environment without any technological enhancements. In order to investigate this, a quasi-experimental non-equivalent comparison group design was used. Similar course content was used for both the control and experimental groups. The students worked through a series of geometry activities and problems. The difference between the groups was that dynamic geometry software was integrated into the teaching of the experimental group. The Cognitive Development and Achievement in Secondary School Geometry (CDASSG) Van Hiele geometry test was used to determine all the students' level of geometric thinking before and after the course. The study found that the use of dynamic geometry software enhanced student teachers' geometric visualisation, analysis and deduction, but not their ability to informally justify their reasoning and to understand the formal aspects of deduction.
\end{abstract}

\section{Background and literature study}

Despite large amounts of money having been invested in equipping schools with technology, there is limited evidence of positive effects on student achievement (Wenglinsky, 1998; Zhao, Pugh, Sheldon \& Byers, 2002). The assumption was that increased availability of technology in the classroom would lead to increased use, and increased use would then lead to not only efficient teaching and better learning, but also better student achievement (Cuban, 2001). According to Brown-L'Bahy (2005), researchers voiced uncertainty about the benefits of school technology use as early as in 1987. In fact, Myhre, Popejoy and Carney (2006, p. 1002) pointed out that there is "considerable uncertainty within the educational community regarding the value of technology in teaching and learning". From these different arguments it is clear that researchers themselves struggle with the question of whether and how technology can improve teaching and learning. There are however researchers who believe that technology, if correctly used, can enhance teaching and learning. Ching, Basham and Planfetti (2005, p. 226) found from research that "student-centered, technologyintegrated learning environments help to produce students who are better able to think critically, solve problems, collaborate with others, and engage deeply in the learning process". According to Sanders (1998), the appropriate use of dynamic geometry software can enhance mathematics teaching and conceptual development, and enrich visualisation, while also laying a foundation for deductive proof. 
Wong (1998) contended that the instructional objective with graphing software is to develop and reinforce concepts, to rectify common errors, to check graphical solutions, to solve equations graphically, to test conjectures through problem posing, to encourage users to become metacognitive, to help users to acquire information technology skills, and to enhance the desire to learn. A study by Usun (2007) suggested that if technology is used for higher-order learning, it can result in increased mathematical achievement. Wang (2008) also argued that technology-supported collaborative learning has a positive effect on students' performance in problem-based tasks.

Guven (2012) explained that the contribution of technology to the teaching and learning of geometry has been associated with the dynamic nature of software such as Cabri, GeoGebra and Geometer's Sketchpad. The power of the dynamic software does not stem only from the possibility of making constructing, it also allows interactive explorations by the dragging of points, vertices and objects:

Once a construction is completed, the user can drag certain elements of it, and the whole construction behaves in such a way that specified constraints are maintained, providing an environment in which students can experiment freely. They can easily test their intuitions and conjectures in the process of looking for patterns ... (Guven, 2012)

The current research aims to investigate whether and how the use of dynamic geometry software, such as Cabri 3D, GeoGebra and Geometer's Sketchpad, influences the cognitive growth of geometry students. The Van Hiele theory was used to measure the cognitive growth of these students. Idris (2009) also used the Van Hiele theory in a study among Form 3 students in one of the secondary schools in Malaysia and found that using Geometer's Sketchpad has promising implications for the potential for teaching geometry at the secondary school. This study, however, did not explain to what extent and how the use of the dynamic software influences the specific Van Hiele levels.

\section{Theoretical framework}

The Van Hiele theory was used to measure the cognitive growth of these students. This theory has made a significant impact upon geometry education, particularly after it became known internationally what its impact had been on Russian mathematics education. Following in the footsteps of Piaget, Pierre and Dina Van Hiele identified five hierarchical, sequential and discrete levels of geometric development that are dependent on a learner's experience. In contrast with Piaget's theory, development is not dependant on age but rather on experience and the quality of instruction. In this context, it is useful momentarily to consider the basic tenets of both Piaget and Van Hiele. Battista and Clements (1995, p. 50) summarised the two theories as follows:

Piaget's theory, on the one hand, describes how thinking in general progresses from being non-reflective and unsystematic, to empirical, and finally to logical-deductive. The theory of Van Hiele, on the other hand, deals specifically with geometric thought as it develops through several levels of sophistication under the influence of a school curriculum.

According to Kotzé (2007, p. 22), Piaget's argument can be put like this: there is a "maturation process" that takes a learner through acquisition, representation and characterisation of spatial concepts. Van Hiele, however, suggested progress through 
thinking on sequential levels as a result of experience. This experience is almost entirely dependent on instruction (Larew, 1999). According to their model, learners have to master a level to be able move to a higher level. The levels, as described by Mason (2009, pp. 4-5) are as follows:

Level 1 (Visualisation): Students recognise figures by appearance alone, often by comparing them to a known prototype. The properties of a figure are not perceived. At this level, students make decisions based on perception, not reasoning.

Level 2 (Analysis): Students see figures as collections of properties. They can recognise and name properties of geometric figures, but they do not see relationships between these properties. When describing an object, a student operating at this level might list all the properties he/ she knows, but may not discern which properties are necessary and which are sufficient to describe the object.

Level 3 (Abstraction): Students perceive relationships between properties and between figures. At this level, students can create meaningful definitions and give informal arguments to justify their reasoning. Logical implications and class inclusions, such as squares being a type of rectangle, are understood. The role and significance of formal deduction are, however, not understood.

Level 4 (Deduction): Students can construct proofs, understand the role of axioms and definitions, and know the meaning of necessary and sufficient conditions. At this level, students should be able to construct proofs such as those typically found in a high school geometry class.

Level 5 (Rigor): Students at this level understand the formal aspects of deduction, such as establishing and comparing mathematical systems. Students at this level can understand the use of indirect proof and proof by contrapositive, and can understand non-Euclidean systems.

The Van Hieles considered the levels to be discrete, but other researchers (Clements \& Battista, 1992; Burger \& Shaughnessy, 1986; Crowley, 1987) argue that since learners develop several Van Hiele levels simultaneously and continuously, it is problematic to assign a learner to a particular level. This is an important reason why this research focuses on the mean scores of the students per level, rather than to assigning students to particular levels.

\section{Research question}

The current study investigates whether the use of dynamic geometry software as an integrated part of instruction is beneficial in increasing students' geometric cognitive growth, measured in terms of the Van Hiele levels.

\section{Research design}

In order to address the above question, a quasi-experimental, non-equivalent comparison group design was used. The reason for this decision was that practically it was not possible to assign the students randomly into two groups because of their timetables. Two geometry classes of a one semester geometry module were used (Table 1). 
Table 1: Non-equivalent comparison group design

\begin{tabular}{|c|c|c|c|}
\hline Group & Pre-test & Treatment & Post-test \\
\hline $\begin{array}{c}\text { Experimental/ technology- } \\
\text { enriched group }\end{array}$ & $\begin{array}{c}\text { CDASSG Van } \\
\text { Hiele Test }\end{array}$ & $\begin{array}{c}\text { Geometry course and tablet } \\
\text { PC GeoGebra and Cabri 3D }\end{array}$ & $\begin{array}{c}\text { CDASSG Van } \\
\text { Hiele Test }\end{array}$ \\
\hline Control group & $\begin{array}{c}\text { CDASSG Van } \\
\text { Hiele Test }\end{array}$ & $\begin{array}{c}\text { Geometry course and } \\
\text { tablet PC }\end{array}$ & $\begin{array}{c}\text { CDASSG Van } \\
\text { Hiele Test }\end{array}$ \\
\hline
\end{tabular}

The study used descriptive statistics, a McNemar Test on each individual test item, and independent $\mathrm{t}$-tests to investigate whether the use of dynamic geometry software as an integrated part of instruction was beneficial in increasing students' level of understanding, as measured in terms of the Van Hiele levels.

\section{Intervention}

The researcher offered a six-month geometry module to two groups of third-year preservice student teachers at the University of Pretoria, South Africa. This module dealt with various aspects of geometry, including Euclidean. Problems and activities were presented and discussed in class, thereby gradually and almost imperceptibly taking students from one level to the next in terms of the development of their thinking. The idea was to start with activities on Level 2 and gradually increase the level of thinking so as to reinforce Levels 3 to 5 . The design of the geometry course was loosely based on the five tenets developed by the Realistic Mathematics Education (RME) movement, as described by Treffers (1987, cited in Bakker, 2004). The first tenet states that "[a] rich and meaningful context or phenomenon, concrete or abstract, should be explored to develop intuitive notions that can be the basis for concept formation" (p. 6). These activities were meant to develop the students' understanding of geometry while solving real-world and theoretical problems. Although there was ample opportunity to integrate and use dynamic geometry software in this course, the course was not designed specifically for a technology-enriched environment. Both the control and experimental groups were taught by the researcher/lecturer with the same amount of contact time.

The researcher used GeoGebra and Cabri 3D in class when teaching the experimental group. These programs allow users to drag vertices and points to investigate and explore mathematical relationships. GeoGebra is an open-source dynamic mathematics software that combines arithmetic, geometry, algebra, statistics and calculus. Cabri 3D enables students and teachers to construct and investigate three-dimensional geometry. It encompasses the benefits of interactive geometry and enables the user to construct, measure, unfold and rotate objects. The experimental group also spent two weeks using GeoGebra in the computer lab. The students in the control group were not exposed in class to either of these software programs. It is however possible that some of the students in the control group had 'informal' access to GeoGebra outside the classroom because it could be downloaded for free.

\section{Examples of activities and how GeoGebra and Cabri 3D were used}

- Activity: If you have a piece of land that is a quadrilateral, what kind of quadrilateral will be formed if you take the midpoint of each of its four sides and join these midpoints? Explain and justify your answer. 
The idea of the activity was firstly to explore and discover that the new quadrilateral EFGH is a parallelogram. The experimental group used GeoGebra to make the construction. The advantage of using GeoGebra is that the mouse could be used to drag the quadrilateral vertices $\mathrm{A}, \mathrm{B}, \mathrm{C}$, and D in order to observe the behaviour of quadrilateral EFGH.

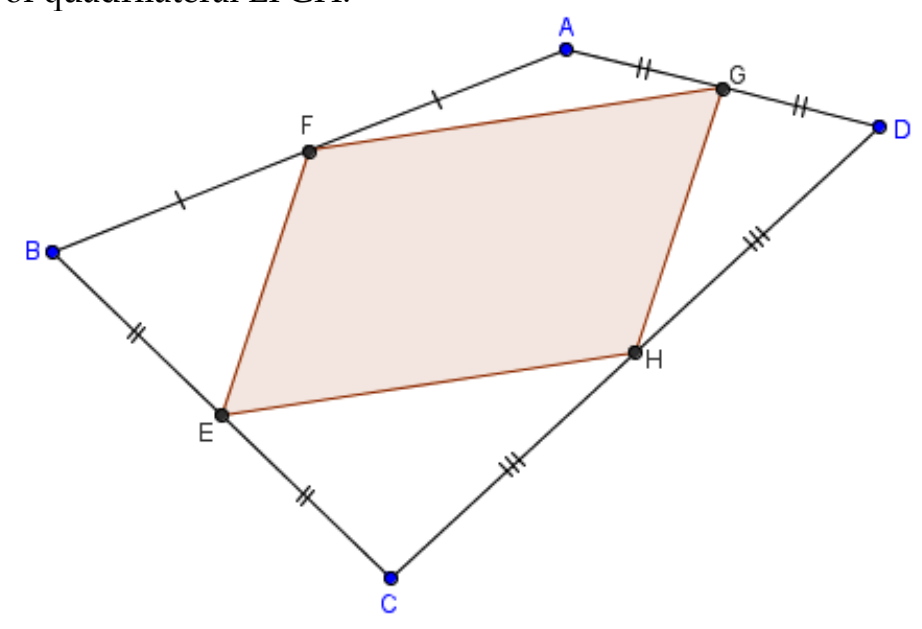

- Activity: If a line is drawn parallel from one side of a triangle, it will divide the other two sides proportionally.

GeoGebra was used by the experimental group to make the construction and to measure the segments accurately. The advantage of using GeoGebra is that the mouse could be used to drag the vertices A, B and C to create more special cases. GeoGebra will measure the segments immediately and also update any calculations.

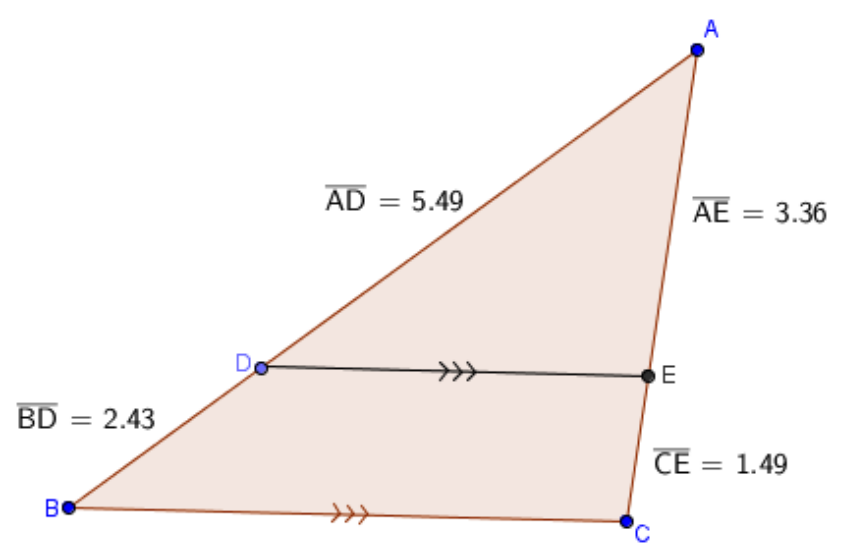

- Activity: Calculate the surface area of the rectangular pyramid with a perpendicular height of $5 \mathrm{~cm}$ and base of $8 \mathrm{~cm}$ by $6 \mathrm{~cm}$.

The idea of the activity was to unfold the pyramid and to draw the net and use Pythagoras Theorem to determine the height of the different triangles. This unfolding was also illustrated in the class of the experimental group by using Cabri $3 D$. 

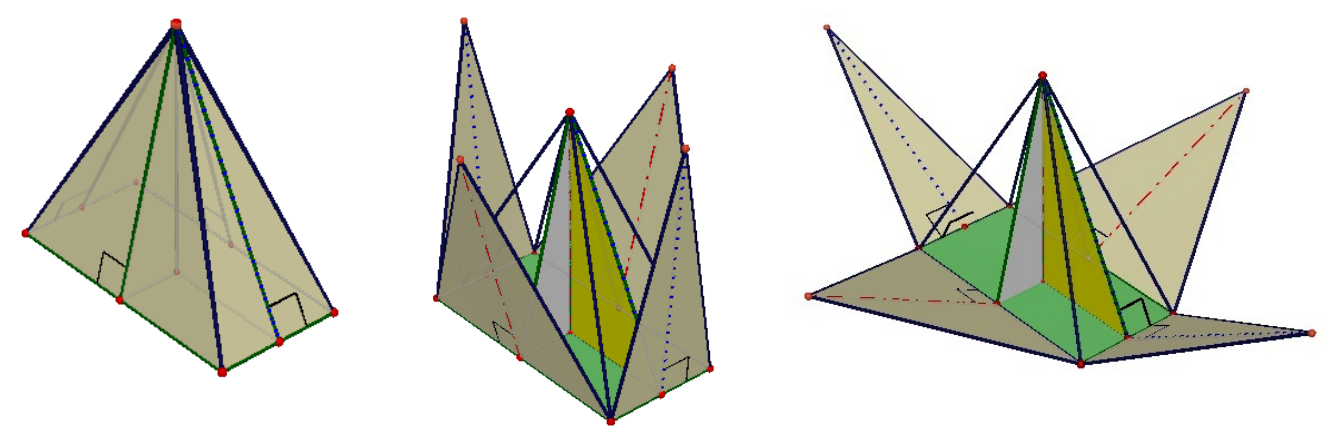

- Activity: What is the sum of the measures of the interior angles of a 1000-gon (a triangle is a 3-gon)?

The idea of the activity was to force students to use inductive thinking. The students could find the pattern for a 3-gon (1 triangle), 4-gon (2 triangles), and 5gon ( 3 triangles) and generalise the pattern. GeoGebra was used by the experimental group to sketch the quadrilaterals and to measure the interior angles.
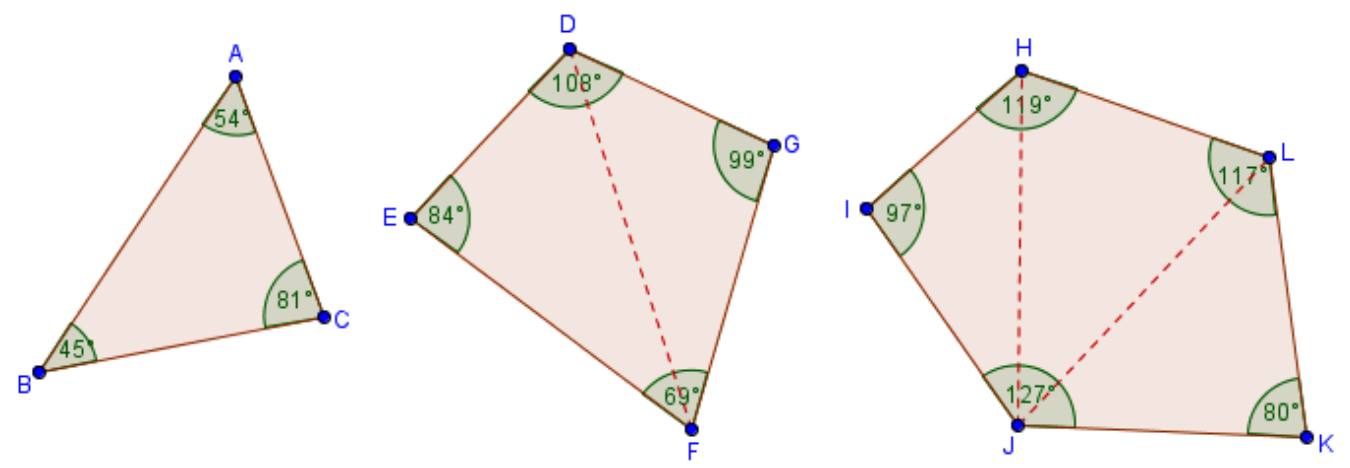

A typical lesson consisted of a short introduction, after which students worked on a series of problems and spontaneously bounced ideas off their classmates. When the majority struggled too much, the researcher intervened and worked with them on specific problems. The nature of the struggling was threefold, in some instances it was limited knowledge of the software, sometimes a lack of content knowledge, and in some instances, limited problem-solving skills. For example, some students struggled to solve the following problem: What is the sum of the measures of the interior angles of a 1000-gon (a triangle is a 3-gon)? Some students lack problem solving skills and tried to construct a 1000-gon using GeoGebra. This approach does not work because it is too tiresome and will take hours. Other students tried to use inductive reasoning but did know how to measure the interior angles in GeoGebra.

\section{Participants}

The students in both the control and experimental groups were third-year BEd preservice teachers who were enrolled for two geometry courses at the University of Pretoria, South Africa. The study used a control group of 55 pre-service teachers and an experimental group of 53 pre-service teachers who were enrolled for the geometry module. These students were selected for the sake of convenience. 


\title{
Research instrument
}

The research instrument that was used was the Cognitive Development and Achievement in Secondary School Geometry (CDASSG) Van Hiele Geometry Test that forms part of the CDASSG project developed by Usiskin (1982). The Van Hiele Geometry Test consists of 25 multiple-choice test questions (five questions on each Van Hiele level). This instrument was selected because it was easy to analyse, well tested, and widely used (permission was obtained from Professor Usiskin to use the test). By using the KuderRichardson Formula 20 in his study (1982), he found that the pre-test reliability of this test was $0.31,0.44,0.49,0.13,0.10$ and $0.39,0.55,0.56,0.30,0.26$ in the post-test for the questions on Van Hiele levels 1, 2, 3, 4, and 5 respectively. According to Larew (1999, p. 37), the construct validity of the instrument was established by Senk in 1989:

\begin{abstract}
Senk found that achievement in writing geometry proofs was positively correlated with Van Hiele level (.50 in the fall and .60 in the spring). Senk also found that in spring the percentage of students who had mastered proof from each spring Van Hiele level was as follows: Level $0-17 \%$; Level 1-22\%; Level 2-57\%; Level 3-85\%; Level 4 $-100 \%$. These data seem to support that Level 3 (as tested by the CDASSG test) is the level at which students master proof and that Level 2 is a transitional level ... These results established the predictive validity of the CDASSG Van Hiele Geometry Test.
\end{abstract}

\section{Data analysis procedure}

Both the experimental and the control group wrote the same pre-test and post-test, namely the CDASSG Van Hiele Geometry Test, before and after their courses were presented. During the first and last contact session students were given 30 minutes to complete the five multiple-choice questions on each of the five Van Hiele levels, thus in total 25 questions.

As a first step, descriptive statistics were used to determine the average scores of students in both the control and experimental groups on each Van Hiele level before and after the course. Secondly, the study employed an independent t-test for each Van Hiele level, to investigate whether the difference between the pre- and post-test was as a result of the use of GeoGebra and Cabri 3D during instruction.

\section{Results and discussion}

The results of the study suggest that the pre-service mathematics teachers did not have a sound understanding of more advanced Euclidian geometry. The most problematic areas were the construction of proofs, understanding the role of axioms and definitions, and an understanding of non-Euclidean systems. There was a definite descending trend from Level 1 (Q1 to Q5) through to Level 4 (Q16 to Q20), as predicted by the literature (see Figure 1). This was, however, not the case with the Level 5 (Q21 to Q25) questions. The students performed slightly better on the Level 5 questions compared to the Level 4 questions. This was contrary to the Van Hiele model, which suggests that mastering on one level is a prerequisite for mastering on the next level. 


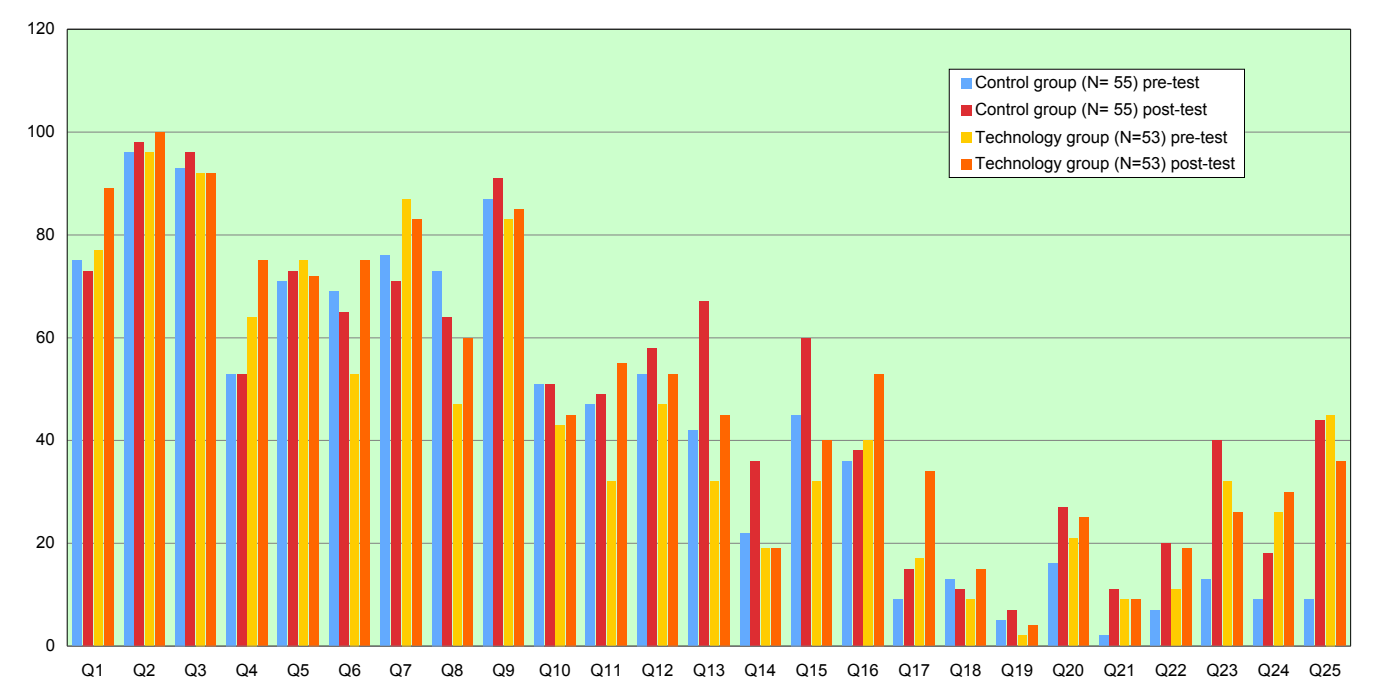

Figure 1: Percentage of students who answered the questions correctly

Although Question 4 was poorly answered compared to the other Level 1 questions (Q1 to Q5), the experimental group did perform slightly better than the control group. The use of dynamic geometry software probably improved students' understanding of the basic definitions and properties of the different quadrilaterals. Question 4 was "Which of these are squares?"

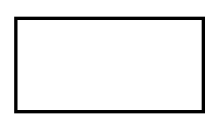

F<smiles>C1CCC1</smiles>

G

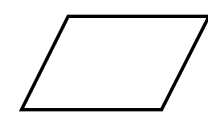

$\mathrm{H}$

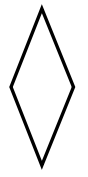

I

A) None of these are squares

B) G only

C) F and G only

D) G and I only

E) All are squares

Figure 2 analyses the selection of distracters as selected by the students. Although only a few students selected distracters A and C, distracters D and E attracted quite a number of students. A possible reason for selecting options D and E could be that some students were under the impression that the inclusion property works in two directions. Students who selected option D defined a square as a quadrilateral with four equal sides.

Students found it difficult to grasp the idea of class inclusion or hierarchical classification, such as a rectangle being a type of a parallelogram. The idea of class inclusion falls typically in the abstraction level of geometrical thought, which is Level 3. This may be the reason why Question 14 was also poorly answered, compared to the other questions (Q11-Q15) on Level 3. 


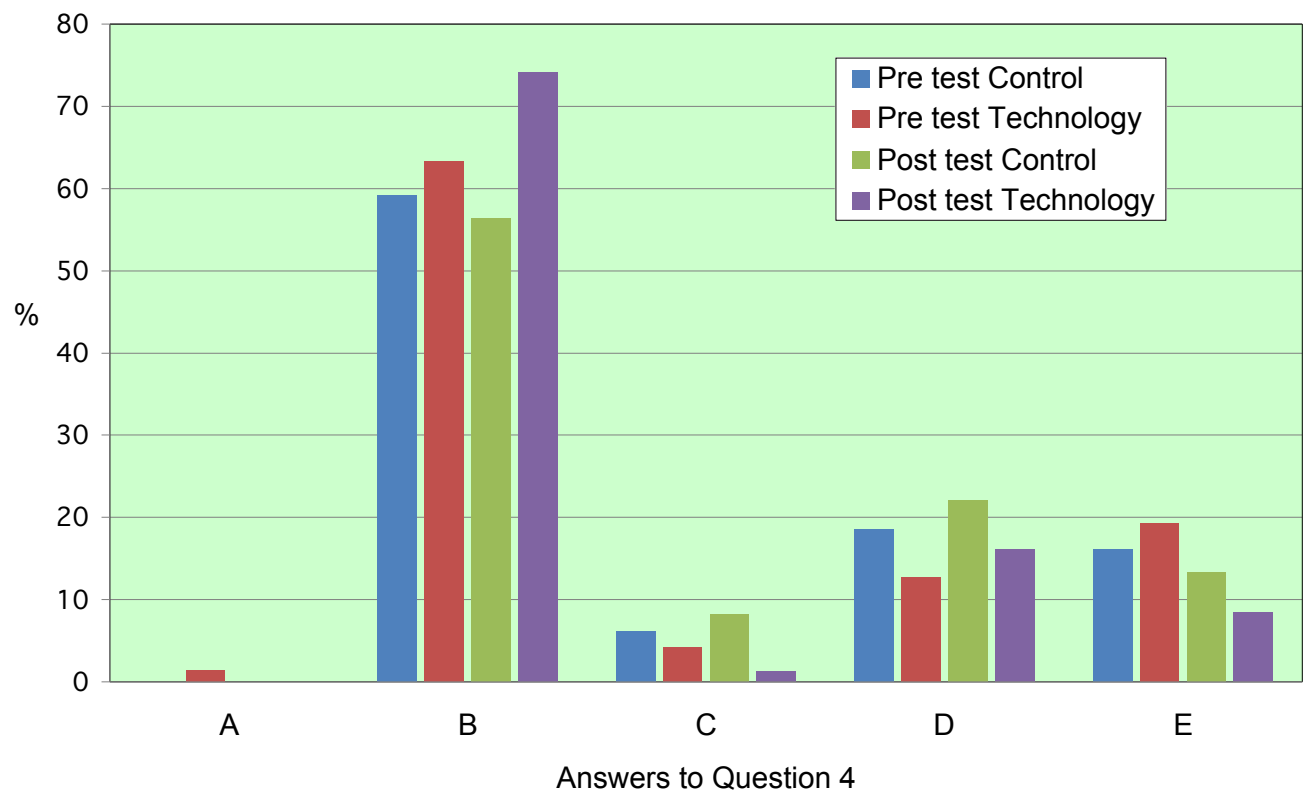

Figure 2: Percentage of students who selected the different distracters (Question 4).

Which of these can be called rectangles?

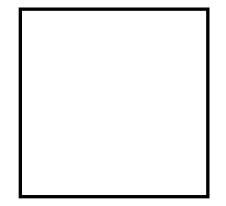

$\mathrm{P}$

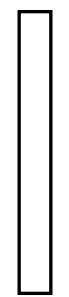

Q

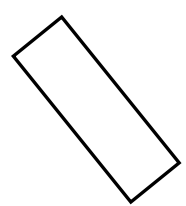

$\mathrm{R}$
A) All can.
B) Q only
C) R only
D) $P$ and $Q$ only
E) $Q$ and R only

The same phenomenon has been identified by other researchers. A study done by Smith (1987) revealed that students find these questions about class inclusion or hierarchical classification consistently more difficult than some higher-level questions (on Levels 4 and 5).

Other outlier questions that were poorly answered compared to other questions on the same level are 10, 19, 21 and 22. These questions will be discussed briefly. Question 10 (Van Hiele Level 2) concerned diagonals, sides and the angle properties of a rhombus. Question 19 (Van Hiele Level 4) focused on the properties of an axiomatic system while questions 21 and 22 (Van Hiele Level 5) dealt with non-Euclidean geometry: 
In F-geometry, which is different from the geometry you are used to, there are exactly four points and six lines. Every line contains exactly two points. If the points are $P, Q, R$ and $S$, and the lines are $\{P, Q\},\{P, R\}$, $\{P, S\},\{Q, R\},\{Q, S\}$, and $\{R, S\}$. Here is how the words "intersect" and "parallel" are used in F-geometry. The lines $\{\mathrm{P}, \mathrm{Q}\}$ and $\{\mathrm{P}, \mathrm{R}\}$ intersect at $\mathrm{P}$ because $\{\mathrm{P}, \mathrm{Q}\}$ and $\{P, R\}$ have $P$ in common. The lines $\{P, Q\}$ and $\{R, S\}$ are parallel because they have no points in common. From this information, which is correct?

A) $\{P, R\}$ and $\{Q, S\}$ intersect.

B) $\{P, R\}$ and $\{Q, S\}$ are parallel.

C) $\{Q, R\}$ and $\{R, S\}$ are parallel.

D) $\{P, S\}$ and $\{Q, R\}$ intersect.

E) None of the above answers (A-D) is correct.

In order to determine the impact of the use and non use of dynamic geometry software on students' understanding of individual questionnaire items, a McNemar test was applied (see Table 2).

Table 2: McNemar Test applied to each individual questionnaire item

\begin{tabular}{|c|c|c|}
\hline \multirow{2}{*}{ Question } & \multicolumn{2}{|c|}{ Chi-square results (Sig. 2-sided) } \\
\cline { 2 - 3 } & Control group & Experimental group \\
\hline Q1 & 1.000 & 0.070 \\
\hline Q2 & 1.000 & 1.000 \\
\hline Q3 & 0.500 & 1.000 \\
\hline Q4 & 1.000 & 0.180 \\
\hline Q5 & 1.000 & 0.774 \\
\hline Q6 & 0.832 & 0.017 \\
\hline Q7 & 0.607 & 0.774 \\
\hline Q8 & 0.383 & 0.167 \\
\hline Q9 & 0.754 & 1.000 \\
\hline Q10 & 1.000 & 1.000 \\
\hline Q11 & 1.000 & 0.017 \\
\hline Q12 & 0.664 & 0.664 \\
\hline Q13 & 0.004 & 0.065 \\
\hline Q14 & 0.096 & 1.000 \\
\hline Q15 & 0.185 & 0.424 \\
\hline Q16 & 1.000 & 0.167 \\
\hline Q17 & 0.508 & 0.078 \\
\hline Q18 & 1.000 & 0.549 \\
\hline Q19 & 1.000 & 1.000 \\
\hline Q20 & 0.238 & 0.815 \\
\hline Q21 & 0.063 & 1.000 \\
\hline Q22 & 0.065 & 0.424 \\
\hline Q23 & 0.001 & 0.629 \\
\hline Q24 & 0.180 & 0.791 \\
\hline Q25 & 0.000 & 0.332 \\
\hline
\end{tabular}

Only two items showed that the use of technology has a statistically significant (below the 5\% confidence level) impact on students' conceptual understanding. That was Q6, which is about the properties of quadrilaterals, and Q11, which is about mathematical logic. Three items in the control group showed that the non-technological intervention had a statistically significant (below the 5\% level) impact on students' conceptual 
understanding. These questions were Q13, Q23 and Q25. Both Q23 and Q25 focused on mathematical rigor and the students' understanding of formal aspects of deduction.

The means were computed to summarise the scores (out of 5) for each Van Hiele level for both the pre- and post-tests (see Table 3). The majority of students did not reach the Van Hiele levels 4 or 5 in both groups and only about half reached Van Hiele level 3. It came as a surprise that not all pre-service students scored full marks on Van Hiele levels 1, 2 and 3 in both the control and experimental groups - not even after the course had been presented.

Table 3: Pre-test and post-test mean scores per Van Hiele level

\begin{tabular}{|c|c|c|c|c|c|c|}
\hline \multirow[t]{2}{*}{ Van Hiele } & \multirow[t]{2}{*}{ Group } & \multirow[t]{2}{*}{$\mathrm{N}$} & \multicolumn{2}{|c|}{$\begin{array}{c}\text { Mean } \\
\text { (out of } 5 \text { ) }\end{array}$} & \multirow{2}{*}{$\begin{array}{c}\text { Mean } \\
\text { improvement } \\
\text { (out of 5) }\end{array}$} & \multirow[t]{2}{*}{ SD } \\
\hline & & & pre-test & post-test & & \\
\hline \multirow[t]{2}{*}{ Level 1} & Control & 55 & 3.87 & 3.93 & 0.05 & 1.161 \\
\hline & Experimental & 53 & 4.06 & 4.28 & 0.23 & 0.847 \\
\hline \multirow[t]{2}{*}{ Level 2} & Control & 55 & 3.56 & 3.42 & -0.15 & 1.161 \\
\hline & Experimental & 53 & 3.13 & 3.49 & 0.36 & 1.272 \\
\hline \multirow[t]{2}{*}{ Level 3} & Control & 55 & 2.09 & 2.71 & 0.62 & 1.459 \\
\hline & Experimental & 53 & 1.62 & 2.11 & 0.49 & 1.476 \\
\hline \multirow[t]{2}{*}{ Level 4} & Control & 55 & 0.80 & 0.98 & 0.18 & 1.073 \\
\hline & Experimental & 53 & 0.89 & 1.30 & 0.42 & 1.232 \\
\hline \multirow[t]{2}{*}{ Level 5} & Control & 55 & 0.40 & 1.33 & 0.93 & 1.215 \\
\hline & Experimental & 53 & 1.25 & 1.21 & -0.04 & 1.224 \\
\hline
\end{tabular}

Comparing the mean improvements of the control and experimental groups in Table 3, it appears that the technology-enriched environment improved the conceptual geometric growth of students in the experimental group on Van Hiele levels 1, 2 and 4. However, there was also evidence of cognitive growth when technology was not used on Van Hiele levels 1, 3, 4 and 5. The negative mean improvement score on Van Hiele level 5 suggests that the technology-enriched environment did not enhance students' understanding of the formal aspects of deduction, such as proofs. In the 'rigor' (Level 5) category (questions that covered the more formal aspects of deduction), the score of the experimental group declined, while the control group improved on average by 0.93 (out of 5) on Van Hiele level 5 questions.

An independent samples t-test was conducted to compare the improvement in scores of the control and the experimental groups for each Van Hiele level. The results of the mean (maximum 5) improvement on each level are presented in Table 3 . The results of the independent t-test show that the only statistically significant difference in the preand post-test scores of the control group was on Van Hiele levels 3 and 5 at $p<.05$ (see Table 4). In the case of the experimental group (technology-enriched) there was a significant difference in the pre- and post-test scores on Van Hiele levels 1, 2, 3 and 4 at $\mathrm{p}<.05$.

\section{Conclusion}

This study sought to use the Van Hiele theory to investigate the geometric cognitive development of students in a technology (dynamic geometry software) enriched environment, compared with students in a learning environment without any technological enhancement. The results suggest that the technology enriched environment helped to improve the conceptual geometric growth of students on Van 
Hiele levels 1, 2 and 4 which is about geometric visualisation, recognition of properties of geometric figures, and the construction of proofs. This finding about the improvements on Van Hiele levels 1 and 2 resonates well with the literature, which suggests that technology can help to create an active learning environment in which students can discover, explore, conjecture and visualise.

Table 4: Paired samples t-test

\begin{tabular}{|c|c|c|c|c|c|c|c|c|}
\hline Van Hiele & Group & Test & Mean & $\mathrm{N}$ & SD & $\mathrm{t}$ & $\mathrm{df}$ & $\mathrm{p}$ \\
\hline \multirow{4}{*}{ Level 1} & \multirow{2}{*}{ Control } & Pre & 3.87 & 55 & 0.904 & \multirow{2}{*}{-3.48} & \multirow{2}{*}{54} & \multirow{2}{*}{0.729} \\
\hline & & Post & 3.93 & 55 & 1.034 & & & \\
\hline & \multirow[t]{2}{*}{ Experimental } & Pre & 4.06 & 53 & .969 & \multirow{2}{*}{-1.947} & \multirow[t]{2}{*}{52} & \multirow[t]{2}{*}{$0.050^{*}$} \\
\hline & & Post & 4.28 & 53 & .769 & & & \\
\hline \multirow[t]{4}{*}{ Level 2} & \multirow[t]{2}{*}{ Control } & Pre & 3.56 & 55 & 1.014 & \multirow[t]{2}{*}{0.929} & \multirow[t]{2}{*}{54} & \multirow[t]{2}{*}{0.357} \\
\hline & & Post & 3.42 & 55 & 1.117 & & & \\
\hline & \multirow[t]{2}{*}{ Experimental } & Pre & 3.13 & 53 & 1.241 & \multirow[t]{2}{*}{-2.051} & \multirow[t]{2}{*}{52} & \multirow[t]{2}{*}{$0.045^{\star}$} \\
\hline & & Post & 3.49 & 53 & 1.137 & & & \\
\hline \multirow[t]{4}{*}{ Level 3} & \multirow[t]{2}{*}{ Control } & Pre & 2.09 & 55 & 1.309 & \multirow[t]{2}{*}{-3.142} & \multirow[t]{2}{*}{54} & \multirow[t]{2}{*}{$0.003^{*}$} \\
\hline & & Post & 2.71 & 55 & 1.370 & & & \\
\hline & \multirow[t]{2}{*}{ Experimental } & Pre & 1.62 & 53 & 1.259 & \multirow[t]{2}{*}{-2.420} & \multirow[t]{2}{*}{52} & \multirow[t]{2}{*}{$0.019^{*}$} \\
\hline & & Post & 2.11 & 53 & 1.354 & & & \\
\hline \multirow[t]{4}{*}{ Level 4} & \multirow[t]{2}{*}{ Control } & Pre & 0.80 & 55 & .931 & \multirow[t]{2}{*}{-1.257} & \multirow[t]{2}{*}{54} & \multirow[t]{2}{*}{0.214} \\
\hline & & Post & 0.98 & 55 & .952 & & & \\
\hline & \multirow[t]{2}{*}{ Experimental } & Pre & 0.89 & 53 & .934 & \multirow[t]{2}{*}{-2.454} & 52 & $0.018^{*}$ \\
\hline & & Post & 1.30 & 53 & .972 & & & \\
\hline Level 5 & Control & Pre & 0.40 & 55 & .627 & -5.660 & 54 & $0.000^{*}$ \\
\hline & & Post & 1.33 & 55 & 1.156 & & & \\
\hline & Experimental & Pre & 1.25 & 53 & 1.090 & 0.224 & 52 & 0.823 \\
\hline & & Post & 1.21 & 53 & .968 & & & \\
\hline
\end{tabular}

* indicates a significance at the 0.05 level (two-tailed)

Dynamic geometry software cannot improve Van Hiele level 4 reasoning directly because deductive reasoning is about the understanding of axioms and the construction of proofs. The question then is why this improvement on Van Hiele level 4 ? According to the Van Hiele theory the use of dynamic geometry software is not rendered worthless on this level. Larew (1999) argues that in order for students to reason at the higher levels, there must be sufficient mastery at the lower levels. De Villiers (2007, p. 55) explained:

This is why I have frequently argued that it is far more meaningful to INTRODUCE proof within a dynamic geometry context, NOT as a way of making sure, but rather as a means of explanation, understanding, and discovery before dealing with the more formal and abstract functions of verification and systematisation.

Although the experimental (technology-enriched) group outperformed the control group on Van Hiele levels 4, this advantage did not materialise in terms of a better understanding on Van Hiele level 5. The results also show that the use of dynamic geometry software, as opposed to a traditional learning environment of the control group, may have a negative impact on the geometric development on Van Hiele levels 3 and 5. These levels are about informal argumentation and the formal aspects of deduction. This result suggests that geometric reasoning at the Van Hiele level 5 (deduction) differs in nature compared to the first 4 levels, which concern visualisation, relationships between properties, informal justification, and proof. 
In fact, several researchers found the last Van Hiele level problematic. Even Pierre Van Hiele (1986, p. 64) himself, writing subsequent to the demise of his wife, admitted that: "It takes nearly two years of continual education to have the pupils experience the intrinsic value of deduction, and still more time is necessary to understand the intrinsic meaning of this concept". Weber (2001, p. 102) found that: "While this research has provided rich data, there is a large and important class of failed proof attempts that it cannot explain. Students often fail to construct a proof because they reach an impasse where they simply do not know what to do." The achievement or lack thereof cannot be accounted for on the grounds of Van Hiele levels alone. Weber (2001, p. 116) concluded that students also need strategic knowledge, but is fully aware of the problematic consequence of the fact: "Since strategic knowledge is heuristic, designing activities that will lead students to acquire this knowledge will be a formidable task." De Villiers (1987, p. 24) pointed out that "two aspects of the Van Hiele theory need clarification and further research, namely a refinement with regard to the levels at which deduction (as justification, explanation and systematisation) is supposed to occur, as well as the relationship between hierarchical thinking and deduction".

Against this background it is understandable that the use of dynamic geometry software does not support the development of the formal aspects of deduction. The results of this study therefore contradict some of the findings of other studies, as mentioned in the literature review, which suggested that the use of technology always supports the development of higher-order thinking.

\section{Limitations}

A limitation of the present study was the fact that the Van Hiele test that focuses on Euclidean geometry was used. The course offered covered not only Euclidian geometry, but also analytical geometry, transformation geometry, and volumes and surface areas. However, this particular test still gave us insight into students' understanding of one of these topics. A possible idea for future research is the development of a new and more comprehensive geometry test.

Another possible limitation of this study in terms of the Van Hiele module is identified by Salomon (2005, p. xvii), who warned that:

Related to this is the assumption that wisely integrating technology into instruction will yield better learning outcomes assessed by the same yardsticks. But this totally ignores the observation that the use of different instructional means afford different kinds of learning activities which, in turn, facilitate the attainment of different kinds of outcomes.

\section{Acknowledgments}

The financial assistance of the Research and Development grant from the University of Pretoria towards this research is hereby acknowledged. Opinions expressed and conclusions arrived at, are those of the author. I want to thank Prof. Z. Usiskin from the University of Chicago for permission to use and copy the CDASSG Van Hiele Geometry Test, and also Prof. F. Steffens for the statistical analyses made.

\section{References}

Bakker, A. (2004). Design research in statistics education: On symbolizing and computer tools. Dissertation: Wilco, Amersfoort. [verified 22 Aug 2012] http:/ / www.stat.auckland.ac.nz/ iase/ publications/dissertations/ 04.Bakker.Dissertation.pdf 
Battista, M. T., \& Clements, D. H. (1995). Geometry and proof. The Mathematics Teacher, 88(1), 4854. http:/ / investigations.terc.edu/library/bookpapers / geometryand_proof.cfm

Brown-L'Bahy, T. (2005). Within and beyond the K-12 classroom: The social contexts of students' technology use. In C. Vrasidas \& G. V. Glass (Eds.), Preparing teachers to teach with technology: current perspectives on applied information technologies (pp. 23-44). Greenwich, CT: Information Age.

Burger, W. F. \& Shaughnessy, J. M. (1986). Characterizing the van Hiele levels of development in geometry. Journal for Research in Mathematics Education, 17(1), 31-48. http:// www.jstor.org/ stable/749317

Ching, C. C., Basham, J. D. \& Planfetti, E. S. (2005). Technology in education, technology in life. In C. Vrasidas \& G. V. Glass (Eds.), Current perspectives on applied information technologies: Preparing teachers to teach with technology (pp. 225-240). Greenwich, CT: Information Age.

Clements, D. H. \& Battista, M. T. (1992). Geometry and spatial reasoning. In D. A. Grouws (Ed.), Handbook of research on mathematics teaching and learning (pp. 420-464). New York: Macmillan.

Crowley, M. (1987). The Van Hiele model of development of geometric thought. In M. Lindquist (Ed.), Learning and teaching geometry K-12 (pp. 1-16). 1987 Yearbook. Reston: National Council of Teachers of Mathematics.

Cuban, L. (2001). Oversold and underused: Computers in the classroom. London: Harvard University Press.

De Villiers, M. D. (1987). Research evidence on hierarchical thinking, teaching strategies and the Van Hiele theory: Some critical comments [Internal RUMEUS report, no 10]. University of Stellenbosch, Stellenbosch, South Africa.

De Villiers, M. D. (2007). Some pitfalls of dynamic geometry software. Teaching and Learning Mathematics, 4, 46-52. http:/ / amesa.org.za/LTM\%204_18.pdf

Guven, B. (2012). Using dynamic geometry software to improve eight grade students' understanding of transformation geometry. Australasian Journal of Educational Technology, 28(2), 364-382. http: / / www.ascilite.org.au / ajet/ajet28/guven.html

Idris, N. (2009). The impact of using Geometers' Sketchpad on the performance in geometry of Malaysian students' achievement and van Hiele geometric thinking. Journal of Mathematics Education, 1(2), 169-180. [verified 22 Aug 2012] http:/ / einspem.upm.edu.my/journal/full paper/vol1no2/2.\%20MJMS\%20vo\%201(2)\%20page\%20169-180.pdf

Kotzé, G. (2007). Investigating shape and space in mathematics: A case study. South African Journal of Education, 27(1), 19-35.

http: / / www.ajol.info/index.php/ saje/ article/viewFile/25096/20765

Larew, L. W. (1999). The effects of learning geometry using a computer-generated automatic draw tool on the levels of reasoning of college developmental students. Unpublished Doctor of Education dissertation, College of Human Resources and Education, West Virginia University. http: / / wvuscholar.wvu.edu:8881 / / exlibris / dtl/d3_1/ apache_media/L2V4bGlicmlzL2R0b C9kM18xL2FwYWNoZV9tZWRpYS8xMzUyNA==.pdf

Mason, M. (2009). The Van Hiele levels of geometric understanding. Professional handbook for teachers: Geometry: explorations and applications. McDougal Littell Inc.

Myhre, O., Popejoy, K. \& Carney, J. (2006). Conditions for technology acceptance in intermediate and middle school mathematics. In C. Crawford et al. (Eds.), Proceedings of Society for Information Technology and Teacher Education International Conference 2006 (pp. 1001-1005). Chesapeake, VA: AACE. http:// www.editlib.org/p/22182 
Salomon, G. (2005). Preface. In C. Vrasidas \& G. V. Glass, (Eds.), Preparing teachers to teach with technology: Current perspectives on applied information technologies (pp. xv-xviii). Greenwich, CT: Information Age Publishers.

Sanders, C. V. (1998). Geometric constructions: Visualizing and understanding geometry. Mathematics Teacher, 91(7), 554-556.

Senk, S. L. (1989). Van Hiele levels and achievement in writing geometry proofs. Journal for Research in Mathematics Education, 20(3), 309-321. http:/ / www.jstor.org/ stable/ 749519

Smith, E. C. (1987). 'n Kwalitatiewe en kwantitatiewe vergelyking van enkele Van Hiele-toets instrumente. Unpublished Master's dissertation, University of Stellenbosch, Stellenbosch.

Usiskin, Z. (1982). Van Hiele levels and achievement in secondary school geometry. (Final Report of the Cognitive Development and Achievement in Secondary School Geometry Project). Chicago, Illinois: University of Chicago. http:/ / ucsmp.uchicago.edu/resources / van_hiele_levels.pdf

Usun, S. (2007). Teacher training programs for computer education and computer assisted education in Turkey. Paper presented at the 7th International Educational Technology (IETC) Conference in Nicosia, Turkish Republic of Northern Cyprus, 3-5 May, 2007. http:/ / www. eric.ed.gov/ERICWebPortal/contentdelivery/servlet/ERICServlet?accno=ED500110

Van Hiele, P. M. (1986). Structure and insight. Orlando: Academic Press.

Wang, Q. (2008). A generic model for guiding the integration of ICT into teaching and learning. Innovations in Education and Teaching International, 45(4), 411-419. http: / / dx.doi.org/10.1080/14703290802377307

Weber, K. (2001). Student difficulty in constructing proofs: The need for strategic knowledge. Educational Studies in Mathematics, 48(1), 101-119. http: / / dx.doi.org/10.1023/ A:1015535614355

Wenglinsky, H. (1998). Does it compute? The relationship between educational technology and student achievement in mathematics. Princeton: ETS Policy Information Center. http: / / www.ets.org/Media/Research/pdf/ PICTECHNOLOG.pdf

Wong, K. Y. (1998). Graphing software: Computers for mathematics instruction (CMI) project. Within and beyond the K-12 classroom: The social contexts of students' technology use. In C. Vrasidas \& G. V. Glass (Eds.), Preparing teachers to teach with technology: Current perspectives on applied information technologies (pp. 23-44). Greenwich, CT: Information Age.

Zhao, Y., Pugh, K., Sheldon, S. \& Byers, J. (2002). Conditions for classroom technology innovations. Teachers College Record, 104(3), 482-515. http: / / www.tcrecord.org/Content.asp?contentid=10850

Author: Dr Gerrit Stols
Department of Science, Mathematics and Technology Education
Faculty of Education (Groenkloof Campus)
University of Pretoria, Pretoria, South Africa
Email: gerrit.stols@up.ac.za

Please cite as: Stols, G. (2012). Does the use of technology make a difference in the
geometric cognitive growth of pre-service mathematics teachers? Australasian Journal of
Educational Technology, 28(7), 1233-1247.
http:// www.ascilite.org.au/ajet/ajet28/stols.html

